\title{
Problematic Aspects of Corporate Tax Risk Empirical Analysis
}

\author{
Strelnik E. U. ${ }^{1}$ Usanova D. S. ${ }^{1} \&$ Khairullin I. G. ${ }^{1}$ \\ ${ }^{1}$ Kazan Federal University, Institute of Management, Economics and Finance, Kazan, 420008, Russia \\ Correspondence: Strelnik E. U., Kazan Federal University, Institute of Management, Economics and Finance, \\ Kazan, 420008, Russia. Tel: 7-927-243-0497. E-mail: jstr06@mail.ru
}

Received: March 19, 2015 Accepted: March 31, 2015 Online Published: April 30, 2015

doi:10.5539/ass.v11n11p374 URL: http://dx.doi.org/10.5539/ass.v11n11p374

\begin{abstract}
Theoretically corporate tax risk is defined as the probability of deviations of the tax burden from the planned values. From the standpoint of tax law there are much more taxation risk factors. The revenue authorities considered as a risk factor not only the amount of the tax burden, but also its fluctuation relative to the average industry value. Besides these, taxation risk factors are: low level of the average wage in a corporation, losses in the company's several tax periods, increase of costs, compared with revenues exceeding the growth rate of tax deductions for VAT, the inconsistency of profitability indicators to average industry values, etc. So, the following question arises: whether the selection of these factors in terms of their relationship to the cost management is justified? Do the taxes and taxation risk in the value of a corporation is essentially? This article is devoted to research these problematical issues.
\end{abstract}

Keywords: risks, tax risks, corporate risks, risk of tax control, tax burden, value based management

\section{Introduction}

Risk category in the broad sense of the term implies at least two approaches to its definition: classical and neoclassical. The classical approach defines risk as a certain probability of an unfavorable outcome of the situation, the loss or damage of any kind, including financial ones. The neoclassical approach considers the risk primarily as a statistical measure of the probability of deviation (in both large and smaller side) of the actual value from the expected. From this viewpoint, tax risk can also be interpreted in two ways. As a rule, the first thing associated with tax risk is the penalties for violation of tax laws or penalties for late payment of taxes. From the standpoint of business practices such interpretation is clear, reasonable and easy to estimate, it is enough to study the chapters 15 and 16 of the Russian Tax Code, and for corporate structures is also a new section V.1 about affiliates.

If we consider the tax risk from a scientific point of view, it is necessary to take into account the neoclassical interpretation and study legal documents. In particular, it is necessary to study in detail the Order of the Federal Tax Service of May 30, 2007 NMM-3-06/333 @ "On approval of the Concept of planning on-site tax audits", where one of the section describes the criteria for self-assessment of the risks to taxpayers. For this purpose, the Federal Tax Service proposes to use the twelve main indicators, one of which is recently introduced for the Russian business practice and theory - the tax burden.

In the years 2004 - 2006 there were a lot of scientific studies of Russian scientists dedicated to the tax burden. If about the calculation of the absolute tax burden a little dispute arises, the majority of authors agree that the figure should include the entire set of taxes and fees paid by the organization, then in terms of the calculation of the tax burden ratio authors suggested various solutions.

Virtually point in this discussion put the Federal Tax Service, defining the tax burden as a ratio of the amount of taxes paid according to the reporting of tax authorities and turnover (revenue) of organizations according to the Federal State Statistics Service (Rosstat). In this case, the tax risk arises if the tax burden of the taxpayer is below its average level for the economic entities in a particular industry (economic activity).

If the tax risk defined as the probability of indicator of the tax burden deviation, in both large and smaller side from the expected value, will be acceptable to designate certain "tax corridor" of indicator values, indicating a risk-free zone. Tax risk arises as a value in excess of the "corridor", and in low value of the index of the tax burden. Too high tax burden means that the organization will pay more taxes than is possible with a certain budget level of economic activity - it will have a negative impact on cash flow and profitability. Too low, 
compared with the average, the tax burden can be a consequence of such actions of the tax authorities, as a request for the documents confirming the data declarations, extraordinary tax audits, etc.

From the viewpoint of corporate finance studying of tax risk in the neoclassical interpretation is extremely important because it affects the choice of effective tax planning strategies. In this case, a measurement of efficiency could be, for example, reduction or complete elimination of penalties for violation of tax laws, reducing or eliminating penalties for late payment of taxes, determination of the tax burden within the risk-free "corridor". However, a more in-depth study of the tax risk requires a scientific approach and finding ways of linking tax indicators with market efficiency indicators, which requires an empirical analysis to identify key indicators associations.

\section{Method}

The main objective of our study was to investigate the relationship between the indicators established by the Federal Tax Service as a tax risk and performance indicators that determine the efficiency of the organization.

For this purpose we have tested the following additional hypotheses.

Hypothesis 1: The negative impact of tax risk indicators (tax burden ratio, the net loss/net income for the fiscal year, the amount of tax deductions for VAT, the average wage, revenue growth, growth of costs, return on assets, the number of affiliates) to market-to-book ratio (MBr) and economic value added (EVA).

Hypothesis 2: Number of company's affiliates weakly negatively correlated with the tax burden of the corporation, i.e. the greater is the number of affiliates, the lower is the tax burden of the company.

To our study we selected 27 large Russian companies (mainly oil and gas industry, metallurgy and mechanical engineering), among which are OJSC "Tatneft", OJSC "Nizhnekamskneftekhim", "Lukoil", JSC "Kazanorgsintez", OJSC "Surgutneftegas", JSC "KAMAZ" and so forth. We analyzed the company's financial statements under RAS for 2009 - 2012 years, according to information posted in the Professional Analysis of Markets and SPARK database.

As the dependent variables we used company's performance indicators, as close as possible to that of the tax risk, recommended by the Federal Tax Service. In our study we analyzed 10 variables (see Table1). In particular we have chosen such factors as: the tax burden (ratio), the net loss/net income for the fiscal year, the amount of tax deductions for VAT, the average wage in the corporation, revenue growth, and growth of costs, return on assets, and the number of affiliates within the organization.

Table 1. The list of variables used to construct the regression model

\begin{tabular}{llll}
\hline & Variable & Type of variable & \\
\hline 1 & Economic value added & the dependent variable & EVA \\
2 & Market-to-book ratio & the dependent variable & MBR \\
3 & Tax burden (ratio) & the independent variable & $\mathrm{HH}_{\text {ratio }}$ \\
4 & Net loss/net profit & the independent variable & $\mathrm{Ub}$ \\
5 & Deductions for VAT & the independent variable & $\mathrm{NV}$ \\
6 & Average wage & the independent variable & $\ln (\mathrm{Zp})$ \\
7 & Revenue growth & the independent variable & $\mathrm{TR}$ \\
8 & Return on assets & the independent variable & $\mathrm{ROA}$ \\
9 & Tax burden, fictitious & the independent variable & $\mathrm{HH}$ \\
10 & Number of affiliates & the independent variable & $\mathrm{Ln}(\mathrm{Af})$ \\
\hline
\end{tabular}

We obtained the following general model (1):

$$
\operatorname{EVA}(\mathrm{MBr})=\alpha+\beta_{1} * \mathrm{HH}_{\text {ratio }}+\beta_{2} * \mathrm{Ub}+\beta_{3} * \mathrm{NV}+\beta_{4} * \ln (\mathrm{Zp})+\beta_{5} * \mathrm{TR}+\beta_{6} * \mathrm{ROA}+\beta_{7} * \operatorname{Ln}(A f)+\varepsilon
$$

In general model, as indicators of company's market efficiency the ratio of the market price of the shares to the account assessment (market-to-book ratio - MBr) and economic value added (EVA) were chosen.

\section{Results}

Impact on the $\mathrm{MBr}$ indicator have X6 (wages) and X10 (affiliates) variables. The model is significant to test the Fisher-Snedecor $(\mathrm{P}<0,01)$. R-squared is equal to 0.143849 , which means almost no material impact on the company's performance of the tax risk ratio to the market price of shares and to the share price in accounting estimate (market-to-book ratio). The results of analysis are presented in the Table 2 and formula 2. 
Table 2. The regression results for the $\mathrm{MBr}$ as dependent variable

\begin{tabular}{cccccc}
\hline Indicators & Coefficient & St. error & t-statistics & P-criteria & Correlation \\
\hline const & 2,45768 & 1,59548 & 1,5404 & 0,12804 & no correlation \\
LN_Zp_X6 & 0,445214 & 0,213747 & 2,0829 & 0,04097 & strong \\
LN_Af_X10 & $-0,435832$ & 0,256213 & $-1,7011$ & 0,09344 & weak \\
\hline
\end{tabular}

$$
\mathrm{MBr}=1,56+0,32 * \operatorname{Ln}(\mathrm{Zp})-0,13 * \operatorname{Ln}(\mathrm{Af})-0,33 * \mathrm{TR}
$$

As to the association between risk and tax indicator of economic value added the presence of a weakly negative correlation is observed. The greatest influence on the rate of economic value added indicators provide the tax burden, revenue growth and whether the company has losses (see Table 3 and formula 3).

Table 3. The regression results for the EVA dependent variable

\begin{tabular}{cccccc}
\hline Indicators & Coefficient & St. error & t-statistics & P-criteria & Correlation \\
\hline const & $-1,84431$ & 0,497101 & $-3,7101$ & 0,00042 & perfect \\
UB_X8 & $-2,73279$ & 1,39009 & $-1,9659$ & 0,05339 & weak \\
TR_fik_X11 & 1,35942 & 0,591452 & 2,2984 & 0,02462 & strong \\
NN_X1 & 0,097741 & 0,0460785 & 2,1212 & 0,03755 & strong \\
Nnfik_X3 & 1,26373 & 0,64177 & 1,9691 & 0,05301 & weak \\
\hline \multicolumn{3}{c}{ EVA $=-3,31-2,83 * \mathrm{Ub}+0,76 * \mathrm{TR}+2,02 * \mathrm{NN}+0,22 * \operatorname{Ln}(\mathrm{Af})$} & $(3)$
\end{tabular}

Due to the fact that one of the hypotheses was confirmed, we performed a more detailed analysis of the regression for companies representing particular industry. Table 4 shows the results of the regression analysis for the oil and gas industry.

Table 4. The regression results for oil and gas companies

\begin{tabular}{ccccc}
\hline Variable & $\begin{array}{c}\text { Coefficient of partial } \\
\text { correlation }\end{array}$ & $\begin{array}{c}\text { t-statistics } \\
(\mathrm{tcr}=1,734)\end{array}$ & $\begin{array}{c}\text { The coefficient of } \\
\text { determination, } \mathrm{R}^{2}\end{array}$ & $\begin{array}{c}\text { F- statistics } \\
(\mathrm{Fcr}=3,179)\end{array}$ \\
\hline Const & $-10,9405$ & $-2,811$ & & 3,686 \\
NN & 3,20191 & 2,6915 & 0,53 & \\
LN(Af) & 0,934992 & 1,9835 & & \\
\hline
\end{tabular}

For the oil and gas industry hypothesis about the impact of tax risk indicators measure on economic value added is confirmed. Statistically significant for the model were the two variables: the tax burden and affiliation of the company. Standardized form of the equation is (4):

$$
\mathrm{EVA}=-10,94+3,20 * \mathrm{NN}+0,93 * \operatorname{Ln}(\mathrm{Af})+\varepsilon
$$

The regression results for the energy industry are presented in the Table 5.

Table 5. The regression results for energy companies

\begin{tabular}{ccccc}
\hline Variable & $\begin{array}{c}\text { Coefficient of partial } \\
\text { correlation }\end{array}$ & $\begin{array}{c}\text { t-statistics } \\
(\mathrm{tcr}=1,734)\end{array}$ & $\begin{array}{c}\text { The coefficient of } \\
\text { determination, } \mathrm{R}^{2}\end{array}$ & $\begin{array}{c}\text { F- statistics } \\
(\mathrm{Fcr}=3,179)\end{array}$ \\
\hline Const & 2,242 & 2,027 & & 3,551 \\
NN & $-0,009$ & $-0,264$ & 0,681 & \\
TR & $-2,041$ & $-2,161$ & & \\
ROA & $-0,739$ & $-0,243$ & & \\
\hline
\end{tabular}

Standardized form of the equation for energy companies is (5):

$$
\mathrm{EVA}=2,242-0,009 * \mathrm{NN}-2,041 * \mathrm{TR}-0,739 * \mathrm{ROA}+\varepsilon
$$

According to this equation (5) it can be concluded that the growth rate has inverse effect on the value added indicator.

The regression results for the iron and steel industry are presented in the Table 6.

We obtained significant regression equation for iron and steel industry, but, all the regression coefficients are not significant.

The regression results for the chemical industry are presented in the Table 7. 
Table 6. The regression results for iron and steel companies

\begin{tabular}{ccccc}
\hline Variable & $\begin{array}{c}\text { Coefficient of partial } \\
\text { correlation }\end{array}$ & $\begin{array}{c}\text { t-statistics } \\
\text { (tcr=1,734) }\end{array}$ & $\begin{array}{c}\text { The coefficient of } \\
\text { determination, } \mathrm{R}^{2}\end{array}$ & $\begin{array}{c}\text { F- statistics } \\
(\text { Fcr }=3,179)\end{array}$ \\
\hline Const & 1,97188 & 2,4191 & & \\
NN & 0,0286 & 2,242 & 0,277 & 2,955 \\
Ln(Af) & $-0,1401$ & $-0,8313$ & & \\
ROA & 0,02965 & 1,7113 & & \\
\hline
\end{tabular}

Table 7. The regression results for chemical companies

\begin{tabular}{ccccc}
\hline Variable & $\begin{array}{c}\text { Coefficient of partial } \\
\text { correlation }\end{array}$ & $\begin{array}{c}\text { t-statistics } \\
(\mathrm{tcr}=1,734)\end{array}$ & $\begin{array}{c}\text { The coefficient of } \\
\text { determination, } \mathrm{R}^{2}\end{array}$ & $\begin{array}{c}\text { F- statistics } \\
(\mathrm{Fcr}=3,179)\end{array}$ \\
\hline Const & 12,695 & 2,1884 & & \\
Ln(Zp) & $-1,49226$ & $-2,2531$ & 0,336 & 3,037 \\
Ln(Af) & $-1,98096$ & $-1,9153$ & & \\
\hline
\end{tabular}

We obtained significant regression equation for chemical industry. Association of studied factors with the resulting index (EVA) coincides with the hypotheses set. However, from the resulting regression coefficients were statistically significant only wage $(\operatorname{Ln}(\mathrm{Zp}))$ and number of affiliates $(\operatorname{Ln}(\mathrm{Af}))$.

The regression results for the engineering industry are presented in Table 8.

Table 8. The regression results for engineering companies

\begin{tabular}{lcccc}
\hline Variable & $\begin{array}{c}\text { Coefficient of partial } \\
\text { correlation }\end{array}$ & $\begin{array}{c}\text { t-statistics } \\
(\text { tcr=1,734) }\end{array}$ & $\begin{array}{c}\text { The coefficient of } \\
\text { determination, } \mathrm{R}^{2}\end{array}$ & $\begin{array}{c}\text { F- statistics } \\
(\text { Fcr }=3,179)\end{array}$ \\
\hline Const & $-0,5528$ & $-0,2595$ & & \\
TR & $-2,001$ & $-4,0546$ & 0,739 & 8,53 \\
Ln(Af) & 0,49568 & 1,2798 & & \\
\hline
\end{tabular}

A situation similar to the energy industry is experiencing in the engineering industry. The model is significant to the Fisher-Snedecor test, where the rate of $\mathrm{P}<0.01$. However, statistically significant for the model was the revenue growth rate (TR).

\section{Conclusion}

Regression analysis by industry show that tax risk, as well as for the total sample, has no significant effect on the company's market capitalization, estimated by MBr and EVA coefficients. Analysis of the impact of tax risk indicators on the value of the company shows mixed results. On the one hand, the study of the total sample of companies shows that this effect is insignificant. On the other hand, the analysis of individual industries such as oil and iron and steel, found a positive correlation. Chemical, energy and engineering industry concluded the opposite: there is a negative association, although not so significant. Hence it can be said that the results comply with hypothesis. With the accumulation of information is expected to hold a series of clarifying studies of this phenomenon.

The negative impact of the tax burden on the economic added value of the company (EVA) was partially confirmed by the regressions, this relationship is significant only in the oil and gas, iron and steel industries, where the impact is positive. Number of affiliates and average wages has a significant positive impact on the indicator EVA in all industries except the energy. Indicators of tax deductions, the return on assets did not have any significant effect on the company's market efficiency.

Number of affiliates does not correlate with tax burden of corporations, the correlation coefficient is 0.09 . The significance of the model for the hypothesis 2 was not confirmed, there is no correlation, Snedecor-Fisher criterion exceeds a value of 0.01 . Overall, the model is not significant.

The use of metrics offers multiple benefits for the company, among which are the following: early identification of trends and issues, represents a source of critical information for control, provides information about the likelihood of achieving target sites, if there is a sign of improvement or contrary a worsening of the situation, helps to make decisions based on information, helps in evaluating performance, leads to a proactive management, improves future estimates and performance, evaluates success and failure and improves customer satisfaction. Businesses are constantly changing, like this modifying risk exposures. It may be that certain key risk indicators which were relevant last year but they might not be this year as well. The measurement of the risk indicators will 
provide added value to the company, if they are implemented in accordance with its operations, they will be reviewed and will be updated continuously (Emil Scarlat, Nora Chirita, Ioana Al. Bradea).

In conclusion, it should be noted that we should continue the research, due to the fact that the sample we used was not sufficiently representative, and includes only 120 observations together. First, it is necessary to expand the panel data by industry, because now the firm conclusions can not be done due to the lack of data for analysis.

\section{References}

Ankudinov, A., \& Lebedev, O. (2014). Investment drivers of shareholder value creation in large publicly traded Russian companies. Investment Management and Financial Innovations, 11(2), 77-85.

Azat, S., \& Salahieva, M. (2014). The analysis of market structure and competition level in basic industries of the Russian Federation petrochemical cluster. Actual Problems of Economics, 4(154), 195-205.

Bagautdinova, N. G., Galeeva, G. T., \& Kundakchyan, R. M. (2013). Development of the corporate management system in the modern context. World Applied Sciences Journal, 27(13), 43-47.

Bagautdinova, N. G., Malakhov, V. P., \& Kundakchyan, R. M. (2013). Development of management system of manufacturing companies on the basis of management accounting elements. World Applied Sciences Journal, 27(13), 53-57.

Beale, L. M. (2004). Putting SEC Heat on Audit Firms and Corporate Tax Shelters: Responding to Tax Risk with Sunshine, Shame and Strict Liability. Journal of Corporation Law, 29, 219.

Boynton, C., Lisowsky, P., \& Trautman, W. B. (2008). E-File, Enterprise Structures, and Tax Compliance Risk Assessment. Tax Notes, 120(11).

Choudhary, P., Koester, A., \& Shevlin, T. J. (2014). Assessing Financial Reporting Risk in the Income Tax Accrual. Georgetown McDonough School of Business Research Paper.

Diller, M., Kortebusch, P., Schneider, G. T., \& Sureth, C. (2014). Do Investors Request Advance Tax Rulings to Alleviate Tax Risk (And Do Tax Authorities Provide Them)? A Joint Taxpayers' and Tax Authorities' View on Investment Behavior. WU International Taxation Research Paper Series No. 2014-6.

Erasmus, D. N. II (2009). Tax Planning as Part of a Tax Risk Management Process. Thomas Jefferson School of Law Research Paper No. 1482423. http://dx.doi.org/10.2139/ssrn.1482423

Freedman, J., Loomer, G. T., \& Vella, J. (2009). Corporate Tax Risk and Tax Avoidance: New Approaches. British Tax Review, 1, 74-116.

Hutchens, M., \& Rego, S. O. (2012). Tax Risk and the Cost of Equity Capital” Rebekah McCarty (2012) “Optimal Tax Risk and Firm Value. Northeastern U. D'Amore-McKim School of Business Research Paper No. 2013-08.

Kim, J.-B., Li, Y., \& Zhang, L. (2011). Corporate Tax Avoidance and Stock Price Crash Risk: Firm-Level Analysis. Journal of Financial Economics, 100, 639-662. http://dx.doi.org/10.1016/j.jfineco.2010.07.007

Safiullin, L. N., Gafurov, I. R., Safiullin, N. Z., \& Bagautdinova, N. G. (2013). Distribution and product selection under uncertainty. Recent Trends in Social and Behaviour Sciences. Proceedings of the 2nd International Congress on Interdisciplinary Behavior and Social Sciences 2013 (pp. 309-313).

Safiullin, M. R., Elstin, L. A., \& Shakirova, A. I. (2012). Evaluation of business and economic activity as a short-term forecasting tool. Herald of the Russian Academy of Sciences, 4, 290-294. http://dx.doi.org/10.1134/S1019331612040053

Scarlat, E., Chirita, N., \& Bradea, I. A. (2012). Indicators and Metrics Used in the Enterprise Risk Management (ERM). Journal of Economic Computation and Economic Cybernetics Studies and Research, 4, 5-18.

Weisbach, D. A. (2002). Taxation and Risk-Taking with Multiple Tax Rates. U Chicago Law \& Economics, Olin Working Paper No. 172. http://dx.doi.org/10.2139/ssrn.359260

\section{Copyrights}

Copyright for this article is retained by the author(s), with first publication rights granted to the journal.

This is an open-access article distributed under the terms and conditions of the Creative Commons Attribution license (http://creativecommons.org/licenses/by/3.0/ 